\title{
PENGEMBANGAN ALAT UKUR KESIAPAN PENDIDIKAN SEKSUAL PADA ANAK-ANAK USIA 11-14 TAHUN
}

\author{
Devi Jatmika \\ Program Studi Psikologi Universitas Bunda Mulia \\ Email:djatmika@bundamulia.ac.id
}

\begin{abstract}
ABSTRAK
Kasus-kasus kekerasan seksual pada anak-anak semakin memprihatinkan begitupula kasus-kasus perilaku seksual pada remaja. Upaya-upaya preventif dilakukan salah satunnya adalah pentingnya pendidikan seksual sejak dini. Anak-anak usia menjelang pubertas perlu memiliki pengetahuan seksualitas sesuai usia mereka agar dapat menjaga diri, memelihara kesehatan reproduksi dan siap menghadapi pubertas secara fisik dan psikologis. Sayangnya, pendidikan seksual di Indonesia masih memiliki arti negatif di mata masyarakat. Kesiapan anak-anak untuk menerima pendidikan seksual adalah awal untuk memahami keseluruhan kondisi seseorang yang membuatnya siap memberikan respon dalam cara tertentu terhadap suatu situasi. Tujuan dari penelitian ini adalah untuk memperoleh alat ukur kesiapan menerima pendidikan seksual pada anak-anak usia 11-14 tahun di Jakarta. Butir-butir dibuat dengan memperhatikan aspek pengetahuan, psikologis dan sosial budaya. Metode penelitian yang digunakan adalah metode penelitian kuantitatif dengan membagikan kuesioner. Jumlah subyek dalam penelitian sebanyak 436 subyek yang berada di lima wilayah di Jakarta. Jumlah butir sebelum pengujian validitas dan reliabilitas alat ukur sebanyak 42 butir. Setelah dilakukan analisis butir per aspek diperoleh 24 butir dengan reliabilitas konsistensi internal aspek pengetahuan 0.689, aspek psikologis 0.726 dan aspek sosial budaya 0.570. Keseluruhan alat ukur memiliki reliabilitas konsistensi internal sebesar 0.819. Alat ukur kesiapan pendidikan seksual tergolong valid dan reliabel. Analisa data tambahan sebagai bagian dari pengembangan alat ukur, bertujuan untuk mengetahui perbedaan kesiapan penerimaan pendidikan seksual dari segi usia dan domisili dengan teknik Chi-Square. Hasil diperoleh adanya perbedaan kesiapan menerima pendidikan seksual ditinjau dari usia $(p=0.000<0.05)$. Begitupula terdapat perbedaan kesiapan pendidikan seksual ditinjau dari domisili $(p=0.000<0.05)$. Hasil analisa kesiapan pendidikan seksual ditinjau dari jenis kelamin menunjukkan tidak ad perbedaan kesiapan pendidikan seksual pada anak laki-laki dan perempuan $(p=0.532>0.05)$.
\end{abstract}

Kata kunci: kesiapan, pendidikan seksual, anak-anak usia 11-14 tahun, reliabilitas, validitas.

\section{PENDAHULUAN \\ Latar Belakang}

Kasus kekerasan seksual pada anak terus terjadi hingga saat ini dan jumlahnya semakin meningkat di Indonesia. Berdasarkan data lembaga perlindungan anak pada tahun 2010 sampai 2014, tercatat 21,6 juta kasus pelanggaran hak anak, di mana 58 persennya dikategorikan sebagai kejahatan seksual (Marniati \& Hermawan, 2015). Polisi dan pihak berwenang di Indonesia menemukan 50.000 kasus pelecehan seksual dalam periode dua tahun dari April 2012 hingga Maret 2014. Namun, ternyata berdasarkan laporan yang dikeluarkan oleh Komisi Nasional Perlindungan Anak tercatat jumlah sebenarnya mencapai 450.000 kasus, dengan 85 persen kasus yang terluputkan terutama kasus dalam keluarga (BBC Indonesia, 2015). Berdasarkan laporan tersebut ditemukan antara lain, dua pertiga pelecehan seksual terhadap anak-anak terjadi dalam lingkungan keluarga atau sekelilingnya; 75 persen korbannya adalah anak-anak perempuan; pelecehan banyak terjadi pada saat anak-anak berusia sekitar 9-12 tahun; para korban sering tidak berbicara sampai menginjak masa remaja atau jauh sesudahnya ketika mereka sudah menyadari apa yang telah terjadi (BBC Indonesia, 2015). Ketua Bidang Sosial Kesehatan dan Kesejahteraan Keluarga Kongres Wanita Indonesia (Kowani), Susianah Affandy, dari data-data kasus kekerasan seksual yang dialami anak-anak ke Polda Metro Jaya, diketahui terdapat empat penyebab anak rentan terhadap kekerasan. Pertama, anak sangat mudah terpengaruh dengan iming-iming yang diberikan pelaku baik dari lingkungan keluarga maupun lingkungan pendidikan. Kedua, anak tidak bisa mengekspresikan apa yang sedang dialami dengan bahasa verbal. Ketiga, anak menggantungkan hidupnya kepada pelaku karena sebagian besar pelaku 
adalah orang terdekat anak tersebut. Keempat, lambatnya korban melaporkan kekerasan yang dialami kepada kepolisian (dalam Akbar, 2015).

Fakta-fakta di atas semakin meyakinkan bahwa pendidikan seksual pada anak adalah sesuatu yang penting untuk dilaksanakan. Akan tetapi, membicarakan tentang masalah seks masih dianggap tabu di masyarakat. Komisioner Komnas Perempuan, Mariana Amiruddin menyebutkan bahwa pendidikan seksual bukanlah soal kepercayaan dan moral namun, manusia sebagai makhluk seksual harus memahami usianya, pertumbuhan seksual, fungsi, cara kerja organ seksual, dan bagaimana cara menjaga alat-alat kelamin tetap sehat. Filosofi pendidikan seks adalah memberi informasi sejelas-jelasnya kepada anak-anak dan masyarakat agar mereka mengetahui perilaku seperti apa yang aman dan mana yang berbahaya serta apa bahayanya (Heldifanny \& Rachmawati, 2016).

Riset dasar Kesehatan (Riskesdas) pada tahun 2010, menyatakan bahwa sebanyak $60.6 \%$ remaja DKI Jakarta belum pernah mendapatkan penyuluhan kesehatan reproduksi. Selain itu, kelompok remaja usia 10-14 tahun merupakan usia dengan pendidikan kesehatan reproduksi terendah (13.7\%) dibandingkann dengan kelompok umur di atasnya (Riskesdas dalam Muktiningrum \& Budiati, 2014). Penelitian yang dilakukan oleh Muktiningrum \& Budiati (2014) mengenai pengetahuan dan sikap terhadap aktivitas seksual pranikah remaja SMP Negeri di Jakarta Timur, menunjukkan sebanyak 12,4 \% berperilaku seksual berisiko berat, 44,7\% memiliki dorongan seksual aktif, 50, 6\% berpengetahuan buruk dan 57,1\% bersikap negatif. Riset dasar Kesehatan (Riskesdas) pada tahun 2010, menyatakan bahwa sebanyak 60.6\% remaja DKI Jakarta belum pernah mendapatkan penyuluhan kesehatan reproduksi. Selain itu, kelompok remaja usia 10-14 tahun merupakan usia dengan pendidikan kesehatan reproduksi terendah (13.7\%) dibandingkan dengan kelompok umur di atasnya (Riskesdas dalam Muktiningrum \& Budiati, 2014).

Dari permasalahan yang terjadi, anak-anak usia menuju pubertas dianggap belum saatnya mengetahui hal-hal seputar seksualitas karena adanya anggapan informasi seksual masih tabu di usia mereka. hal ini membuat anak-anak bertanya-tanya dan mencarin infrmasi yang salah. Maka dari itu kesiapan anak-anak untuk menerima pendidikan seks perlu diketahui. Dalam pengembangan instrument kesiapan pendidikan seksual ini ditujukan pada anak-anak usia 11-14 tahun. Kesiapan adalah keseluruhan kondisi seseorang yang membuatnya siap untuk memberikan respon atau jawaban dalam cara tertentu terhadap suatu situasi (Slameto, 2010). Menurut Yusuf (dalam Fajri dan Khairani, 2011) ada 3 aspek mengenai kesiapan untuk menerima pendidikan seksual, yaitu :

a. Aspek pemahaman, yaitu kondisi di mana seseorang mengerti dan mengetahui kejadian yang dialaminya, yang bisa dijadikan sebagai salah satu jaminan bahwa dia akan merasa siap menghadapi hal-hal yang terjadi

b. Aspek penghayatan, yaitu sebuah kondisi psikologis di mana seseorang siap secara alami bahwa segala hal yang terjadi secara alami akan menimpa hampir semua orang ada sesuatu yang wajar, normal, dan tidak perlu dikhawatirkan

c. Aspek kesediaan, yaitu suatu kondisi psikologis di mana seseorang sanggup atau rela untuk berbuat sesuatu sehingga dapat mengalami secara langsung segala hal yang seharusnya dialami sebagai salah satu proses kehidupan.

Dalam penelitian ini, kesiapan pendidikan seksual terdiri dari: 1). aspek pemahaman: pengetahuan mengenai perubahan-perubahan tubuh menjelang pubertas secara umum; 2). Aspek psikologis yang merupakan gabungan dari penghayatan menghadapi pubertas dan kesediaan 
untuk belajar/ motivasi (Yusuf dalam Fajri dan Kairani, 2011). Peneliti menambahkan aspek ketiga yaitu aspek sosial budaya yang mencakup pandangan mengenai seksualitas dari sudut pandang norma yang berlaku di masyarakat dan peran sosial budaya mendukung pendidikan seksual. Penelitian sebelumnya mengenai kesiapan pendidikan seks belum pernah dilakukan. Oleh karena itu, dalam penelitian ini berusaha mengembangkan alat ukur kesiapan pendidikan seks, mengingat pentingnya pendidikan seks untuk usia remaja awal.

\section{METODE PENELITIAN}

Metode penelitian yang digunakan untuk pengembangan instrument adalah metode penelitian kuantitatif. Teknik pengambilan sampling yang digunakan adalah convenience sampling, yaitu pengambilan sampel berdasarkan kesediaan responden untuk menjadi sampel penelitian (Gravetter \& Forzano, 2012).

Responden dalam penelitian adalah anak-anak berusia 11-14 tahun di Jakarta. Pembagian kuesioner dilakukan ke lima wilayah di Jakarta: Jakarta Utara, Jakarta Barat, Jakarta Pusat, Jakarta Timur dan Jakarta Selatan. Jumlah sampel dalam penelitian sebanyak 436 orang. Penyebaran kuesioner dilakukan di sekolah-sekolah di Jakarta dan secara random dibagikan kepada responden yang mengisi kuesioner. Jumlah total butir dalam instrument adalah 42 butir. Contoh-contoh butir instrument kesiapan menerima pendidikan seksual disusun berdasarkan tiga aspek. Pertama, aspek pengetahuan sebanyak 12 butir dengan contoh butir: "Saya mengetahui bahwa seks bebas adalah seks yang dilakukan sebelum menikah", "Hubungan suami istri seharusnya dilakukan oleh pasangan yang sudah menikah". Aspek kedua yaitu aspek psikologis sebanyak 15 butir, dengan contoh butir: "Menuju pubertas adalah sesuatu yang normal di usia saya.", "Saya ingin mendapatkan informasi mengenai seksualitas dari guru, orang tua, atau seminar-seminar". Aspek ketiga, sosial budaya sebanyak 15 butir, dengan contoh butir: "Pada usia saya, perlu untuk mempelajari kesehatan organ seksual", "Membicarakan mengenai perkembangan reproduksi ketika usia remaja jarang sekali dilakukan di keluarga saya".

Teknik analisa data untuk mengetahui validitas dan realibilitas alat ukur mengacu pada Kuder Richardson 20 (KR-20), yang mana butir dengan nilai cronbach alpha if item deleted lebih besar dari nilai cronbach alpha maka butir dinyatakan gugur.

\section{HASIL DAN PEMBAHASAN}

\section{Hasil}

Dalam penyusunan instrument kesiapan pendidikan seksual, prosedur yang dilakukan yaitu: 1) melakukan focus group discussion yang bertujuan untuk mengetahui sejauh mana mereka mengetahui tentang pendidikan seksual; 2) Face validity, untuk mengetahui sejauh mana pemhaman anak atas kalimat dalam instrument; 3) Content validity yang dilakukan oleh pakar; 4) Pengumpulan data kepada responden; 5) Pengolahan data melakukan uji reliabilitas dan validitas; 6) Analisis hasil.

Dari hasil face validity dan masukan dari guru sekolah, instrument menggunakan skala dikotomi yaitu $0=$ tidak dan $1=$ ya (aspek pengetahuan dan aspek sosial budaya), $0=$ tidak sesuai dan $1=$ sesuai (aspek psikologis). Skala ini digunakan untuk memudahkan anak-anak dalam memberikan respon. Responden dalam penelitian diperoleh sebanyak 436 orang. 


\section{Gambaran Deskriptif Subjek}

Pada tabel 1 menunjukkan gambaran subjek berdasarkan jenis kelamin. Jumlah anak berjenis kelamin laki-laki sebanyak 211 orang (48.4\%) dan perempuan sebanyak 225 orang (51.6\%).

Tabel 1. Gambaran Deskriptif Subjek berdasarkan Jenis Kelamin

\begin{tabular}{lll}
\hline Jenis kelamin & Frekuensi & Persentase \\
\hline Laki-laki & 211 & $48.4 \%$ \\
Perempuan & 225 & $51.6 \%$ \\
\hline Total & 436 & $100 \%$ \\
\hline
\end{tabular}

Pada tabel 2, gambaran subyek berdasarkan usia diketahui jumlah anak berusia 11 tahun sebanyak 43 subyek (9.8\%), usia 12 tahun sebanyak 118 subyek (27.1\%), usia 13 tahun sebanyak 118 subyek (27.1\%) dan usia 14 tahun sebanyak 157 subyek (36\%).

Tabel 2. Gambaran Deskriptif Subjek berdasarkan Usia

\begin{tabular}{lll}
\hline Usia & Frekuensi & Persentase \\
\hline 11 tahun & 43 & $9.8 \%$ \\
12 tahun & 118 & $27.1 \%$ \\
13 tahun & 118 & $27.1 \%$ \\
14 tahun & 157 & $36 \%$ \\
\hline Total & 436 & $100 \%$ \\
\hline
\end{tabular}

Gambaran subyek berdasarkan domisili dapat dilihat di tabel 3. Subyek yang berdomisili di Jakarta Utara sebanyak 118 subyek (27.1\%), Jakarta Barat sebanyak 58 subyek (13.3\%), Jakarta Pusat 69 subyek (15.8\%), Jakarta Timur 88 subyek (20.2\%), dan Jakarta Selatan 103 (23.6\%). 
Tabel 3. Gambaran deskriptif subyek berdasarkan domisili

\begin{tabular}{lcc}
\hline Domisili & Frekuensi & Persentase \\
\hline Jakarta Utara & 118 & 27.1 \\
Jakarta Barat & 58 & 13.3 \\
Jakarta Pusat & 69 & 15.8 \\
Jakarta Timur & 88 & 20.2 \\
Jakarta Selatan & 103 & 23.6 \\
\hline Total & 436 & 100 \\
\hline
\end{tabular}

\section{Hasil Uji Validitas dan Reliabilitas}

Hasil uji reliabilitas dan validitas alat ukur diperoleh pada aspek pemahaman dari 12 butir terdapat 1 butir gugur sehingga jumlah butir valid adalah 11 butir dengan nilai reliabilitas setelah butir valid adalah 0.689. Pada aspek psikologis, dari 15 butir terdapat 6 butir gugur sehingga diperoleh 9 butir valid dengan reliabilitas setelah uji validitas 0.726 . Pada aspek sosial budaya, dari 15 butir terdapat 7 butir tidak valid, nilai relibilitas setelah uji adalah 0.570 . Hasil uji validitas dan reliabilitas dapat dilihat pada tabel 5.

Tabel 5. Hasil Uji Validitas dan Relabilitas Aspek Kesiapan Pendidikan Seksual

\begin{tabular}{|c|c|c|c|c|c|c|}
\hline Aspek & $\begin{array}{l}\text { Jumlah } \\
\text { butir } \\
\text { sebelum } \\
\text { uji }\end{array}$ & $\begin{array}{l}\text { Nomor } \\
\text { butir } \\
\text { gugur }\end{array}$ & $\begin{array}{l}\text { Jumlah } \\
\text { butir } \\
\text { setelah uji } \\
\text { validitas } \\
\end{array}$ & $\begin{array}{l}\text { Reliabilitas } \\
\text { sebelum uji }\end{array}$ & $\begin{array}{l}\text { Reliabilitas } \\
\text { setelah uji }\end{array}$ & Kesimpulan \\
\hline $\begin{array}{l}\text { Pemahaman/ } \\
\text { pengetahuan }\end{array}$ & 12 & 12 & 11 & 0.673 & 0.689 & $\begin{array}{l}\text { Cukup } \\
\text { Reliabel }\end{array}$ \\
\hline Psikologis & 15 & $\begin{array}{l}28, \quad 29, \\
30, \quad 35, \\
41,42\end{array}$ & 9 & 0.634 & 0.726 & Reliabel \\
\hline Sosial budaya & 15 & $\begin{array}{lr}3, & 4, \\
8, & 14, \\
15, & 18 \\
22, & 23, \\
26, & 33\end{array}$ & 4 & 0.388 & 0.570 & $\begin{array}{l}\text { Kurang } \\
\text { reliabel }\end{array}$ \\
\hline
\end{tabular}

Secara keseluruhan alat ukur kesiapan pendidikan seks untuk anak-anak usia 11-14 memiliki nilai reliabilitas sebesar 0.819, maka dari itu dapat dikatakan alat ukur reliabel. Hasil reliabilitas alat ukur kesiapan pendidikan seks setelah butir dibuang dapat dilihat pada tabel 6 . 
Tabel 6. Hasil Uji Validitas dan Reliabilitas Kesiapan Pendidikan Seksual

\begin{tabular}{lllll}
\hline Variabel & Reliabilitas & Mean & SD & Jumlah butir \\
\hline $\begin{array}{l}\text { Kesiapan } \\
\text { pendidikan seks }\end{array}$ & 0.819 & 17.63 & 4.31 & 24 \\
\hline
\end{tabular}

\section{Hasil uji data tambahan}

Berdasarkan uji distribusi Kolmogorov Smirnov Test menujukkan data terdistribusi tidak normal $(0.000<0.05)$. Maka dari itu, analisis data untuk melihat perbedaan kesiapan pendidikan seksual berdasarkan usia, jenis kelamin dan domisili di Jakarta menggunakan analisis statistik non parametrik.

Peneliti melakukan analisa tambahan dari data subyek. Pada tabel 7, hasil analisa uji perbedaan kesiapan menerima pendidikan seksual ditinjau dari jenis kelamin dengan teknik analisa Mann Whitney $U$ diperoleh nilai 2.292 dengan $\mathrm{p}=0.532>0.05$, hal ini menunjukkan tidak ada perbedaan kesiapan pendidikan seks pada laki-laki dan perempuan.

Tabel 7. Kesiapan Pendidikan Seks Ditinjau dari Jenis Kelamin

\begin{tabular}{llll}
\hline Jenis kelamin & Mean & Mann Whitney & Signifikansi \\
\hline Laki-laki & 214.62 & 2.292 & 0.532 \\
Perempuan & 222.14 & & \\
\hline
\end{tabular}

Kesiapan pendidikan seks ditinjau dari domisili dengan analisis Kruskal Wallis diperoleh nilai koefisien Chi Square sebesar 121.578 dengan $p=0.000<0.05$. Hal ini menunjukkan adanya perbedaan kesiapan pendidikan seks berdasarkan domisili (Jakarta Utara, Jakarta Barat, Jakarta Timur, Jakarta Pusat dan Jakarta Selatan). Hasil koefisien Chi Square dapat dilihat di tabel 8.

Tabel 8. Kesiapan Pendidikan Seks Ditinjau dari Domisili

\begin{tabular}{ll}
\hline & Nilai \\
\hline Chi-Square & 121.578 \\
Sig & .000 \\
\hline
\end{tabular}

Hasil uji perbedaan dengan analisis Kruskal Wallis untuk mengetahui perbedaaan kesiapan pendidikan seksual berdasarkan usia, diperoleh nilai Chi square sebesar 121.95 dengan $\mathrm{p}=0.000$ $<0.05$, hal ini menunjukkan adanya perbedaan kesiapan pendidikan seksual ditinjau dari usia.

Tabel 9. Kesiapan Pendidikan Seks Ditinjau dari Usia

\begin{tabular}{ll}
\hline & Nilai \\
\hline Chi-Square & 121.95 \\
Sig & .000 \\
\hline
\end{tabular}




\section{Pembahasan}

Hasil dari penelitian menunjukkan bahwa alat ukur kesiapan pendidikan seks tergolong reliabel. Sebagaimana tujuan dari pendidikan seks adalah memberikan pengertian yang memadai mengenai perubahan fisik, mental, dan proses kematangan emosional yang berkaitan dengan masalah seksual pada anak sampai remaja; mengurangi ketakutan dan kecemasan mengenai perkembangan dan penyesuaian seksual (peran, tuntutan, dan tanggung jawab); memberikan pengertian mengenai kebutuhan nilai moral yang esensial untuk memberikan dasar yang rasional dalam membuat keputusan yang berhubungan dengan perilaku seksual; memberikan kesalahan dan penyimpangan seksual agar individu dapat menjaga diri dan melawan eksploitasi yang dapat mengganggu kesehatan fisik dan mentalnya (Safita, 2013). Dengan memberikan pendidikan seks yang tepat, tidak akan menimbulkan kesalahpahaman dalam penerimaan informasi. Sehingga sejauh mana pemahaman anak tentang seks, kesiapan psikologis dan peran sosial budaya mendukung kesiapan pendidikan seks menjadi aspek dalam pengembangan alat ukur. Pada aspek pemahaman merupakan pengetahuan seputar perubahan tubuh menjelang pubertas dan seks sebagai fungsi reproduksi. Penelitian kualitatif yang dilakukan oleh Marpaung dan Setiawan (2012) pada anak remaja usia 11-18 tahun diketahui pemahaman responden tentang pendidikan seks adalah tentang perilaku seksual. Pendidikan seks berbeda dengan seks itu sendiri. Pendidikan seks merupakan upaya memberikan pengetahuan perubahan biologis dan psikososial sebagai akibat pertumbuhan dan perkembangan manusia dengan menanamkan nilai moral, etika dan komitmen agama (Thera dalam Marpaung \& Setiawan, 2012). Penelitian lain yang dilakukan oleh Luthfiya (2016) kepada siswi SD usia 9-11 tahun di Surabaya diketahui pengetahuan responden memiliki pengaruh signifikan terhadap kesiapan menghadapi menarche. Tingkat kesiapan terendah dimiliki oleh $50 \%$ responden dengan pengetahuan yang kurang, sedangkan tingkat kesiapan tertinggi dimiliki responden dengan tingkat pengetahuan baik $85.7 \%$.

Aspek psikologis merupakan aspek penghayatan yang berkaitan dengan kondisi psikologis dimana seseorang siap secara alami bahwa segala hal yang terjadi secara alami akan menimpa hampir semua orang sebagai sesuatu yang wajar, normal dan tidak perlu dikhawatirkan (Yusuf dalam Fajri dan Khairani, 2011). Faktor psikologis juga dapat mempengaruhi proses pikir dan mempengaruhi mental seseorang. Menurut Slameto (dalam Kristyari, 2017) aspek psikologis yang dapat mempengaruhi kesiapan adalah kematangan, kecerdasan, keterampilan, kemampuan dan minat, motivasi dan kesehatan. Penelitian yang dilakukan oleh Kristyari (2017) ditemukan adanya pengaruh antara pendidikan kesehatan dengan kesiapan psikologi remaja putri prapubertas menghadapi menarche di SDN 1 Kerambitan $(\mathrm{p}=0.001)$.

Pengaruh sosial budaya turut mempegaruhi kesiapan anak dalam menerima pendidikan seks. Pemahaman anak terkait tata cara hidup bermasyarakat diperoleh dari sumber-sumber di lingkungan sekitarnya. Dimulai dari keluarga, masih banyak orang tua yang berangggapan pendidikan seks adalah mengajarkan anak untuk melakukan reproduksi secara seksual (KPAI, 2016). Pandangan tabu untuk membicarakan seks antara orangtua dan pendidik kepada anak, menurut pandangan psikoanalisis dikarenakan seks merupakan dorongan "id" yang bertentangan dengan "moral" yang ada dalam super ego, sehingga tidak boleh dimunculkan dalam perilaku terbuka, sehingga remaja umumnya tidak mau mengakui aktivitas seksual dan sangat sulit untuk berdiskusi tentang seks (Rogel \& Zuechlke dalam Sarwono, 2013). Pada umumnya remaja yang memasuki usia remaja tanpa pengetahuan yang memadai tentang seks, selama hubungan pacaran akan menambah informasi-informasi yang salah. Hal ini ditambah pula dengan kurangnya komunikasi orangtua dan anak menyebabkan anak mencari dan memperoleh informasi dari sumber-sumber yang tidak akurat seperti dari teman, majalah-majalah dan internet (Sarwono, 
2013). Perkembangan moral juga dapat berperan dalam kesiapan pendidikan seks. Menurut Kohlberg (dalam Lahey, 2008) perilaku moral dipengaruhi oleh pola asuh orangtua dan perkembangan moral. Sebagaimana pada anak-anak usia 11-14 tahun, perkembangan moral ditandai dengan kemampuan anak untuk memahami aturan, norma dan etika yang berlaku di masyarakat. Pengembangan moral termasuk nilai-nilai agama merupakan hal yang sangat penting dalam membentuk sikap dan kepribadian anak, misalnya mengenalkan anak pada nilainilai agama dan memberikan pengarahan terhadap anak tentang hal-hal yang terpuji dan tercela.

Latar belakang responden dalam pengisian instrument turut mempengaruhi reliabilitas dan validitas dari instrumen, seperti usia, tempat tinggal dan jenis kelamin. Hasil analisa tambahan, diketahui adanya perbedaan kesiapan pendidikan seksual ditinjau dari usia $(\mathrm{p}=0.000<0.05)$, yang mana anak-anak berusia lebih muda masih dalam tahap transisi dan duduk di kelas VI SD, mereka belum mendapatkan pengetahuan atau informasi seksual dari sekolah secara formal dalam kurikulum, sehingga banyakpula anak-anak yang masih awam degan istilah "pendidikan seks" dan belum mengetahui dan mengalami perubahan-perubahan pra pubertas. Sedangkan anak-anak yang telah di bangku SMP dan telah mengalami pra pubertas lebih memahami maksud dari butir-butir yang disampaikan. Faktor dari lingkungan yang mendukung sejauh mana penerimaan informasi mengenai perubahan seksual menjelang pubertas. Adanya perbedaan kesiapan pendidikan seks ditinjau dari domisili responden $(\mathrm{p}=0.000)$ tidak lepas dari lingkungan dan tempat anak setiap harinya berinteraksi dan belajar. Anak-anak belajar dari orang-orang di sekelilingnya dan mulai berpikir menurut pola-pola tempat mereka tinggal sehingga akan mempengaruhi perkembangan seksualitas (Martono \& Sarwono dalam Muhafilah \& Husniawati, 2014). Kesiapaan pendidikan seks menunjukkan tidak adanya perbedaan kesiapan ditinjau dari jenis kelamin, yang berarti anak laki-laki dan perempuan memiliki kesiapan yang sama untuk menerima pendidikan seks. Hal ini dapat dikarenakan mereka memiliki rasa ingin tahu akan pubertas dan ingin memperoleh pendidikan seks dari sumber yang dipercaya dan reliabel, sebagaimana mereka berada dalam usia perkembangan masa pubertas yang dialami perempuan rata-rata berumur 12,5 tahun sedangkan laki-laki diawali pada umur 14,5 tahun (Hurlock, 2007).

\section{KESIMPULAN DAN SARAN}

Kesimpulan dalam penelitian ini, pada instrumen kesiapan pendidikan seksual tergolog reliabel dengan nilai reliabilitas 0.819. Namun pada aspek sosial budaya perlu dikaji ulang karena banyaknya butir yang gugur dan reliablitas yang rendah $\alpha=0.570$. Saran untuk penelitian selanjutnya perlu memperhatikan kata-kata yang lebih sederhana untuk responden usia 11-12 tahun pada instrumen. Selain itu, pada penelitian selanjutnya, dapat memperhatikan faktor pola asuh, faktor inteligensi, religiusitas dan keterkaitannya terhadap kesiapan anak menerima pendidikan seksual.

Saran praktis untuk masyarakat adalah perlu menyadari pentingnya informasi-informasi seksual agar anak lebih terbuka dan mengenal perubahan-perubahan pada tubuh mereka serta tidak mengganggap membicarakan dan memberikan informasi seputar seksualitas tidak patut di norma masyarakat. Anak-anak perlu mengenal lebih mendalam alasan mengapa mereka perlu belajar mengenal dan menjaga bagian tubuh dan organ reproduksi yang tidak semata aturan-aturan boleh atau tidak boleh seputar seksualitas. Pendidikan seks hendaknya mencakup pesan moralitas sebagai uoaya preventif dari perilaku seksual remaja yang beresiko. 


\section{Ucapan Terima Kasih}

Ucapan terima kasih kepada DIKTI yang telah memberikan kesempatan melalui program hibah penelitian, Universitas Bunda Mulia, rekan kerja, asisten mahasiswa dan sekolah-sekolah serta responden yang terlibat dalam penelitian ini.

\section{REFERENSI}

Akbar, M. (2015, Januari 17). Inilah empat penyebab anak rentan alami kekerasan seksual. Diunduh dari http://www.republika.co.id/berita/nasional/umum/15/01/17/nibxkl-inilahempat-penyebab-anak-rentan-alami-kekerasan-seksual

BBC Indonesia. (2015, November 24). Ribuan kasus pelecehan seks anak terluputkan. Diunduh dari http://www.bbc.com/indonesia/majalah/2015/11/151124_majalah_laporan_pelecehanana $\mathrm{k}$.

Cohen, R., \& Swerdlik, M. E. (2010). Psychology testing and assessment. United State: McGraw Hill.

Fajri, A., \& Khairani, M. (2011). Hubungan antara komunikasi ibu-anak dengan kesiapan menghadapi Menstruasi Pertama (Menarche) pada Siswa SMP Muhammadiyah Banda Aceh. Jurnal Psikologi Undip, 10(2), 133-143.

Gravetter, F.J., \& Forzano, L.B., (2012). Research methods for the behavioral sciences $\left(4^{\text {th }}\right.$ $E d$.). Canada : Wadsworth Cengage Learning.

Hurlock, E. B. (2007). Psikologi perkembangan: Suatu pendekatan sepanjang rentang kehidupan. Jakarta: Erlangga.

Heldifanny, R. A., \& Rachmawati, K. D. (2016, April 27). Pendidikan seks di Indonesia: Tabu atau bermanfaat?. Diunduh dari http://www.economica.id/2016/04/sexeducation/

Hilmansyah, H. "Pentingnya Pendidikan Seks Sejak Dini” . (t.th). Diunduh 29 Februari 2016 dari http://www.tabloid-nakita.com/read/2355/pentingnya-pendidikan-seks-sejak-dini.

Lahey, B. (2011). Psychology: An introduction. NY: McGraw- Hill Education.

Luthfiya (2016). Analisis kesiapan siswi Sekolah Dasar dalam menghadapi menarche. Jurnal Biometrika dan Kependudukan, 5(2), 135-145.

Marniati dan Hermawan, B. (2015, Oktober 9). Indonesia Darurat Kekerasan Seksual Anak. (9 Oktober 2015). Diunduh 29 Februari 2016 dari http://nasional.republika.co.id/berita/nasional/umum/15/10/09/nvyiqc354-indonesiadarurat-kekerasan-seksual-anak.

Slameto. (2010). Belajar dan faktor-faktor yang mempengaruhinya. Jakarta: Rineka Cipta.

Yuniarti, D. (2007). Pengaruh pendidikan seks terhadap sikap mengenai seks pranikah pada remaja.

Marpaung, J. S. R., \& Setiawan (2012). Pengalaman remaja dalam menerima pendidikan seks. Jurnal Keperawatan Holistik, 1(1), 35-40. 